\title{
Studi tentang pengaruh bentuk umpan buatan terhadap hasil tangkapan ikan selar (Caranx melamphygus) pada pancing noru di sekitar rumpon
}

\author{
Study on the effect of artificial bait forms on trevally (Caranx melamphygus) catch in \\ noru handline around FADs
}

\author{
ANDIKA LA ODE*, ALFRET LUASUNAUNG dan WILHELMINA PATTY \\ Program Studi Pemanfaatan Sumberdaya Perikanan, Fakultas Perikanan dan Ilmu Kelautan, \\ Universitas Sam Ratulangi, Manado 95115
}

\begin{abstract}
Noru handline generally consists of a reel, main line, leader line, branch lines, swivels, hooks, artificial lures, and sinker. This study aims to compare the effect of artificial bait shape in noru handline on total catch of trevally (Caranx melamphygus), and to determine the best artificial bait for trevally in the waters of Manado Bay. Data collected based on experimental methods that carried out fishing experiments using different forms of artificial baits. Data were analyzed using a Randomized Block Design to test hypothesis $\mathrm{H}_{\mathrm{o}}$ : different forms of artificial bait does not affect the total catch and $\mathrm{H}_{1}$ : different forms of artificial baits affect the total catch. The total catch of trevally were 2456 fish. The statistical analysis resulted to accept $\mathrm{H}_{\mathrm{o}}$ and it can be concluded that all three forms of artificial fishing lures showed no difference on catching trevally and all the bait forms has the same ability on catching trevally.
\end{abstract}

Keywords: noru, artificial baits, trevally, Bay of Manado

\begin{abstract}
ABSTRAK
Pancing noru pada umumnya terdiri dari penggulung, tali utama, tali pengantar, tali cabang, kili-kili, mata pancing, umpan buatan, dan pemberat. Penelitian ini bertujuan untuk membandingkan pengaruh bentuk umpan buatan pancing noru terhadap jumlah hasil tangkapan ikan selar (Caranx melamphygus), dan menentukan bentuk umpan buatan pancing noru yang terbaik terhadap jumlah hasil tangkapan ikan selar di perairan sekitar Teluk Manado. Pengumpulan data dilakukan dengan metode eksperimental, yaitu melakukan percobaan penangkapan ikan selar dengan menggunakan bentuk umpan buatan yang berbeda. Data hasil tangkapan dianalisis dengan menggunakan Rancangan Acak Kelompok untuk menguji hipotesis $\mathrm{H}_{\mathrm{o}}$ : bentuk umpan buatan tidak berpengaruh terhadap hasil tangkapan ikan selar, dan $\mathrm{H}_{1}$ : bentuk umpan buatan berpengaruh terhadap hasil tangkapan ikan selar. Hasil tangkapan diperoleh ikan selar sebanyak 2456 ekor. Hasil analisis menghasilkan menerima $\mathrm{H}_{\mathrm{o}}$ dan dapat disimpulkan bahwa ketiga bentuk umpan buatan pancing noru yang digunakan dalam penelitian ini menunjukkan tidak ada perbedaan terhadap hasil tangkapan ikan selar dan ketiga bentuk umpan tersebut juga mempunyai kemampuan menangkap ikan selar yang sama.
\end{abstract}

Kata kunci: noru, umpan buatan, selar, Teluk Manado

\section{PENDAHULUAN}

Teknik penangkapan ikan yang menggunakan pancing biasa disebut dengan line fishing. Istilah lain juga biasa disebut dengan hook and line atau angling, yaitu alat penangkapan yang terdiri dari tali dan mata pancing. Umumnya pada mata pancing diberi umpan, baik umpan alami maupun umpan buatan yang berfungsi untuk menarik perhatian ikan. Umpan alami dapat berupa ikan,

\footnotetext{
*Penulis untuk penyuratan; email: dhyka.algazali@gmail.com
} 